\title{
Detection of fungi using a long-period fibre grating
}

\author{
${ }^{1}$ Gambhir M., ${ }^{1}$ Gupta S., ${ }^{2}$ John P., ${ }^{3}$ Mahakud R., ${ }^{3}$ Kumar J. and ${ }^{3}$ Prakash O. \\ ${ }^{1}$ ECED, SVNIT, Surat, India, sgupta@eced.svnit.ac.in \\ ${ }^{2}$ Department of Plant Pathology, Navsari Agriculture University, Navsari, India \\ ${ }^{3}$ Laser System Engineering Division, RRCAT, Indore, India
}

Received: 04.12 .2016

\begin{abstract}
We present the first-time application of long-period fibre gratings written with a copper-vapour laser for detection of fungi in plants. The long-period gratings are used for identification of Trichoderma fungi species. A significance of our work lies in the facts that these bioagents protect plant roots against pathogens that can cause serious fungal diseases, resulting in great crop yield losses and, moreover, these can cause a lethal effect on human beings. We study such Trichoderma species as T. Harzianum, T. Viride and T. Longibacterium. They reveal characteristic attenuation peaks respectively at the resonance wavelengths 1524,1520 and $1522 \mathrm{~nm}$. The corresponding transmission dips change from $63.75 \mathrm{~dB}$ for the case of water to $54.85,57.34$ and $59.76 \mathrm{~dB}$ for the cases of water solutions of T. Harzianum, T. Viride and T. Longibacterium, respectively.
\end{abstract}

Keywords: long-period fibre gratings, surrounding refractive index, linearly polarized modes.

PACS: 07.07.Df, 42.81.Pa

UDC: 535.8

\section{Introduction}

Long-period gratings are widely known as unique ultrafast and highly stable surrounding refractive-index sensors. Various applications of these gratings have been reported in the literature, including sensing of physical parameters [1-5], adulteration detection [6-10] and detection of harmful radiation [11]. Recently the sensors based on the long-period gratings have been used for studying E. Coli bacteria [12] and human serum [13].

Early detection of pathogens like bacteria, viruses and fungi in crops can reduce the damage caused to agriculture. Each of the traditional detection methods used for this aim (e.g., the standard methods termed as PCR, FISH and ALISA) reveals both benefits and limitations. Real-time processing, high sensitivity and capability to operate in harsh environments are still the important requirements in this area. All across the globe, crop infections causing food losses are among persistent issues. In contrast to chemical compounds, biofungicides prove to be useful bioagents for managing efficiently greenhouse vegetables and floriculture crops [14]. Since the biofungicides do not cure any pre-existing pathogen, they have to be applied before the onset of disease development. Their inherent benefits include stability, safety and a negligible toxic effect upon the host plants [15]. In spite of a number of benefits provided by utilization of biofungicides as bioagents, they also pose a serious, even lethal, threat to some immuno-compromised and immuno-suppressed humans. Moreover, a well-known Trichoderma species have been reported as a source causing a green-mould disease in plants [16-19]. As a consequence, fast and reliable detection of fungi can be a boon to the agriculture industry.

In the present paper, we have demonstrated a very reliable and fast method for detecting

Ukr. J. Phys. Opt. 2017, Volume 18, Issue 2 77 
fungi that employs the long-period gratings. Namely, we have identified three Trichoderma species such as T. Harzianum, T. Viride and T. Longibacterium with $2 \times 10^{7} \mathrm{cfu} / \mathrm{gm}$, using so-called long-period fibre gratings (LPFGs).

\section{Brief introduction of the method}

Propagation of light in LPFGs can be simplified by assuming linearly polarized modes. Coupling of the fundamental guided mode $\mathrm{LP}_{01}$ and the cladding modes $\operatorname{LP}_{0 m}(m>1)$, which co-propagate in a LPFG, results in a series of resonant attenuation peaks in the optical transmission spectrum. It is governed by the phase-matching condition given as [6]

$$
\lambda_{\text {res }}=\left[n_{\text {effco }}(\lambda)-n_{\text {effcl }, m}(\lambda)\right]
$$

Here $\lambda_{\text {res }}$ is the resonance wavelength, $n_{\text {effco }}(\lambda)$ the effective refractive index of the fundamental core mode, $n_{\text {effcl, } m}(\lambda)$ the effective refractive index of the $m$-th cladding mode, and $\Lambda$ the grating period. Note that the both parameters $n_{\text {effco }}(\lambda)$ and $n_{\text {effcl, } m}(\lambda)$ are functions of the light wavelength.

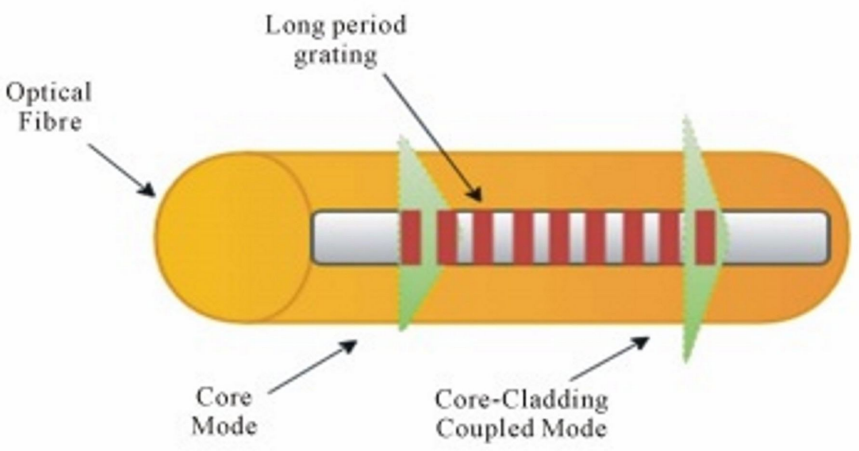

Fig. 1. Schematic illustration of LPFG used as a surrounding refractive-index sensor.

LPFGs are known to have high refractive-index sensitivity if compared to their counterparts, e.g. fibre Bragg gratings. Since the evanescent field of the coupled mode in a LPFG extends much further into the surrounding, the grating can be used as a good surrounding refractive-index sensor (see Fig. 1).

\section{Experimental results}

Fig. 2 shows a setup for writing LPFGs based on a point-by-point method. For this aim we used an ultraviolet beam $(255 \mathrm{~nm}, 5.6 \mathrm{kHz}, 30 \mathrm{~ns}$ and $40 \mu \mathrm{J})$ generated from the second-harmonic conversion of a copper-vapour laser beam $(510 \mathrm{~nm})$ with a BBO crystal (Casix, $4 \times 4 \times 7 \mathrm{~mm}^{3}$ and a $51^{\circ}$-cut working at a type-I phase matching at $\lambda=510 \mathrm{~nm}$ ) [20]. The second-harmonic beam was spatially separated and collimated to a diameter $2.5 \mathrm{~mm}$. The profile of the ultraviolet beam was nearly 'top hat' and its divergence was equal to $120 \mu \mathrm{rad}$ for the beam with a $10 \mathrm{~mm}$ diameter.

Our workstation incorporated computer-controlled translation stages capable to move along $\mathrm{X}, \mathrm{Y}$ and $\mathrm{Z}$ directions, a magnetic clamped $\mathrm{V}$-groove fibre holder, a beam-shaping optics, and an LPFG spectrum interrogation system. A microcontroller-based setup could be programmed to control both the displacement of a fibre (with the resolution $2 \mu \mathrm{m}$ and the maximum translation 
$25 \mathrm{~mm}$ ) and the ultraviolet-exposure time. In this way we fabricated long-period gratings with the period $289 \mu \mathrm{m}$. Then the fibre ends were fused with the patch cords and connected to a light source and an optical spectrum analyzer to monitor a real-time increase in the transmission minimum of the LPFG spectrum during fabrication.

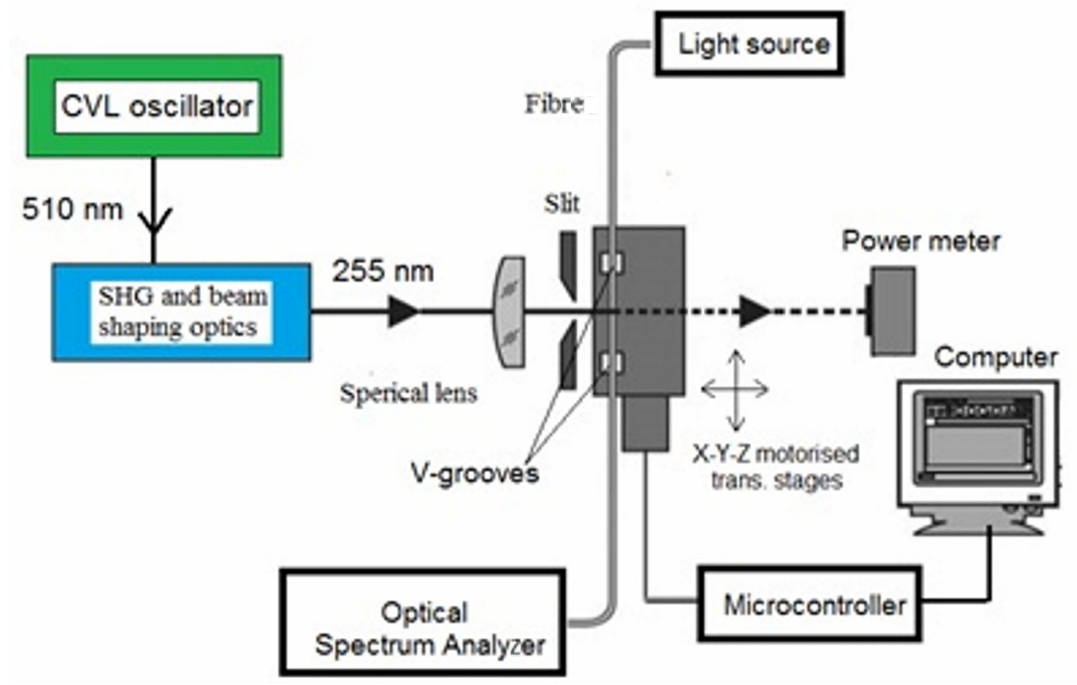

Fig. 2. Setup for recording LPFGs: CVL denotes the copper-vapour laser and SHG the second-harmonic generation.

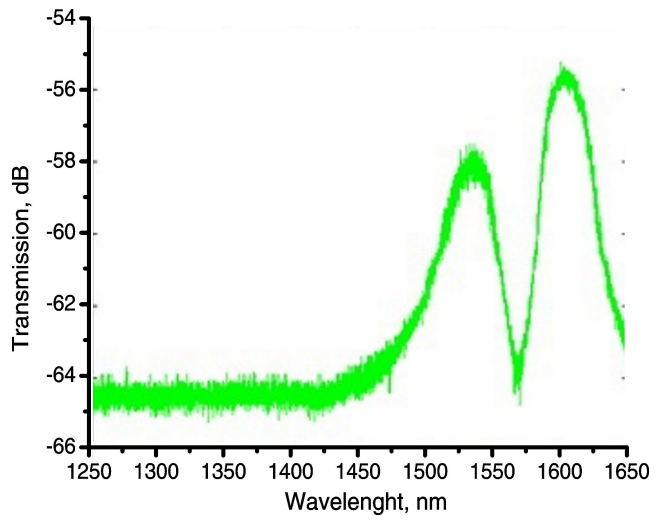

Fig. 3. Optical transmission spectrum of our LPFG with the period $289 \mu \mathrm{m}$ written using a point-by-point method.

Fig. 3 shows a typical transmission spectrum of the LPFG written as described above. This LPFG written in a single-mode photosensitive fibre (Fibercore PS1250/1500) has been used for the qualitative analysis of Trichoderma species. The latter have been prepared after taking $1 \mathrm{~g}$ of Trichoderma sample taken in sterile distilled water and preparing a $10^{-6}$ dilution. $1 \mathrm{ml}$ of this solution $\left(10^{-6}\right)$ was transferred to sterile Petri plates and $15 \mathrm{ml}$ of a molten cooled potato dextrose agar was added to these Petri plates. The plates were incubated for 5 days at the room temperature. The average population numbers of the colonies were counted. A minimum colony-forming unit with $2 \times 10^{7} \mathrm{cfu} / \mathrm{gm}$ has been obtained. Solutions of the three samples mentioned above in deionized water were prepared and analyzed using our LPFGs. A superluminescent light-emitting diode was used as a broadband source covering the region from 1480 to $1600 \mathrm{~nm}$. An optical spectrum analyzer Prolite-60 with the wavelength range $1250-1650 \mathrm{~nm}$ was used to monitor the transmission spectra of our LPFGs.

Ukr. J. Phys. Opt. 2017, Volume 18, Issue 2 


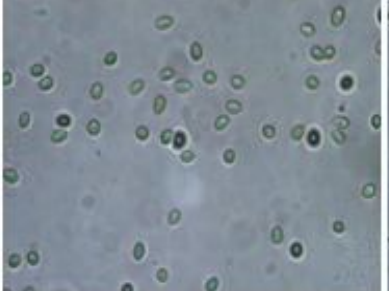

(a)

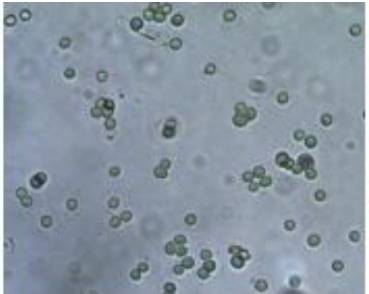

(b)

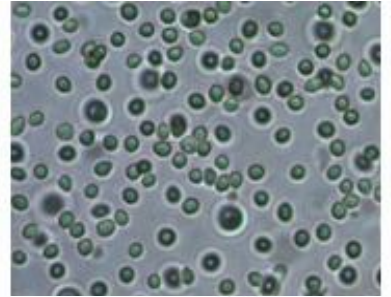

(c)

Fig. 4. Microscopic images of T. Harzianum (a), T. Viride (b) and T. Longibacterium (c).

Fig. 4 shows the images of our T. Harzianum, T. Viride and T. Longibacterium samples, as taken using the microscope. Our investigations have demonstrated that different attenuation losses are observed for different Trichoderma species. Fig. 5a shows the transmission spectrum of the LPFG immersed in deionized water. Fig. 5b displays the spectra obtained for the three Trichoderma species relative to the spectrum in water. The resonance wavelength located at $1526 \mathrm{~nm}$ is shifted towards 1524,1520 and $1522 \mathrm{~nm}$ respectively for the cases of T. Harzianum, T. Viride and T. Longibacterium. The corresponding transmission dips reduce from $63.75 \mathrm{~dB}$ to $54.85,57.34$ and $59.76 \mathrm{~dB}$, respectively. Table 1 summarizes the results for the three samples. The shifts of the peak wavelength in the transmission spectra are accompanied by the changes in the attenuation peaks. These can be attributed to the changes in the coupling coefficients due to changing surrounding refractive index. Notice that different LPFGs were used for the different samples to maintain biosafety and reduce the errors.

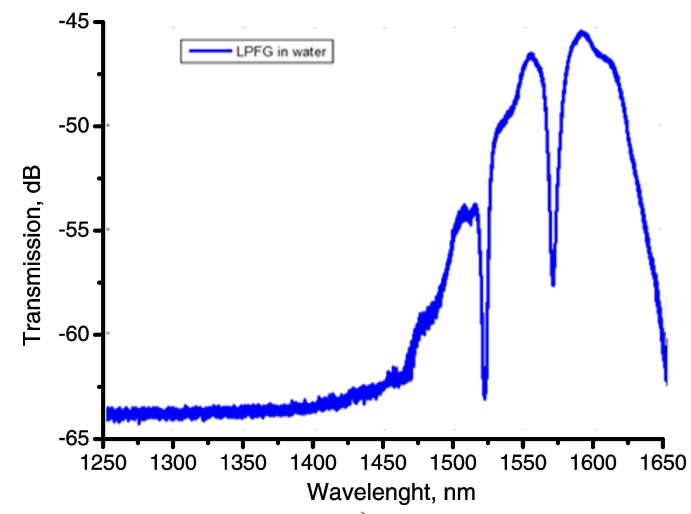

a)

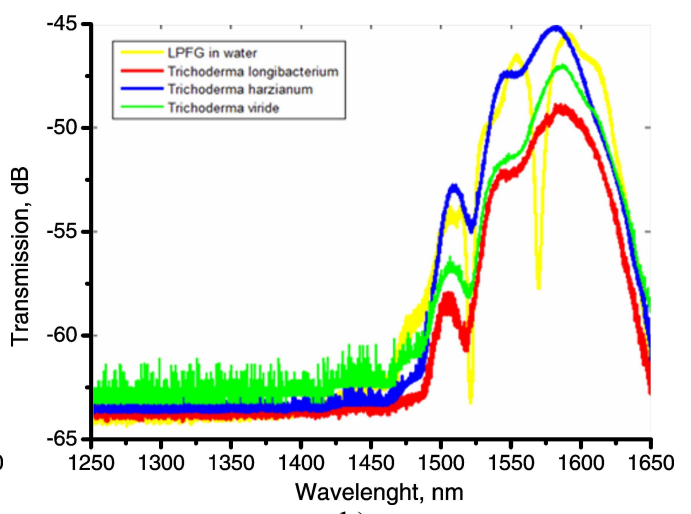

b)

Fig. 5. Transmission spectra of LPFG immersed into water (a) and into water containing the Trichoderma samples (b).

Table 1. Transmission loss peaks and peak wavelengths found for our samples of Trichoderma.

\begin{tabular}{|c|c|c|c|}
\hline Sample number & Trichoderma species & Peak, dB & Wavelength, nm \\
\hline 1 & T. Harzianum & 54.85 & 1524 \\
2 & T. Viride & 57.34 & 1522 \\
3 & T. Longibacterium & 59.76 & 1520 \\
\hline
\end{tabular}

\section{Conclusion}

In conclusion, we have demonstrated for the first time that the LPFGs can be used for identification of the Trichoderma species T. Harzianum, T. Viride and T. Longibacterium, which work as useful bioagents in protecting plants from pathogens. It has been shown that the T. Harzianum, T. Viride and T. Longibacterium species reveal notable shifts in the loss peaks, when compared 
with distilled water. These peaks shift from $63.75 \mathrm{~dB}$ to $54.85,57.34$ and $59.76 \mathrm{~dB}$ at the resonance wavelengths 1524,1520 and $1522 \mathrm{~nm}$, respectively for the three species mentioned. The present study can extend the scopes for identifying the other Trichoderma species with the LPFGbased sensors, including the species characterized by changing concentrations in samples.

\section{Acknowledgements}

We wish to acknowledge Shri S. V. Nakhe, a Head of Laser System Engineering Division and Dr. S. K. Dixit, a Head of Metal Vapour and Dye Laser Application Lab., RRCAT, for their technical support in writing long-period gratings, which have contributed greatly to this work. We are also thankful for financial support of our experimental work under the TEQIP II grant.

\section{References}

1. Vengsarkar A M, Lemaire P J, Judkins J B, Bhatia V, Erdogan T and Sipe J E, 1996. Longperiod fiber gratings as band-rejection filters. J. Lightwave Technol. 14: 58-65.

2. Bhatia V, 1999. Applications of long-period gratings to single and multi-parameter sensing. Opt. Express. 4: 457-466.

3. Wang Y P, Xiao L, Wang D N and Jin W, 2006. Highly sensitive long-period fiber-grating strain sensor with low temperature sensitivity. Opt. Lett. 31: 3414-3416.

4. Taghipour A, Rostami A, Bahrami M, Baghban H and Dolatyari M, 2014. Comparative study between LPFG-and FBG-based bending sensors. Opt. Commun. 312: 99-105.

5. Shu X, Allsop T, Gwandu B, Zhang L and Bennion I, 2001. High-temperature sensitivity of long-period gratings in B-Ge codoped fiber. IEEE Photon. Technol. Lett. 13: 818-820.

6. Kher S, Chaubey S, Kishore J and Oak S M, 2013. Detection of fuel adulteration with high sensitivity using turnaround point long period fiber gratings in $\mathrm{B} / \mathrm{Ge}$ doped fibers. IEEE Sensors J. 13: 4482-4486.

7. Hochreiner H, Cada M and Wentzell P D, 2008. Modeling the response of a long-period fiber grating to ambient refractive index change in chemical sensing applications. J. Lightwave Technol. 26: 1986-1992.

8. Mishra V, Jain S C, Singh N, Poddar G C and Kapur P, 2008. Fuel adulteration detection using long period fiber grating sensor technology. J. Sci. Industr. Res. 46: 106-110.

9. Libish T M, Linesh J, Biswas P, Bandyopadhyay S, Dasgupta K and Radhakrishnan P, 2010. Fiber optic long period grating based sensor for coconut oil adulteration detection. Sensors \& Transducers. 114: 102-111.

10. Libish T M, Linesh J, Bobby M C, Biswas P, Bandypadhyay S, Dasgupta K and Radhakrshnan P, 2011. Fiber optic sensor for the adulteration detection of edible oils. Optoelectron. Adv. Mat. - Rapid Commun. 5: 68-72.

11. Kher S, Chaubey S, Kashyap R and Oak S M, 2012. Turnaround-point long-period fiber gratings (TAP-LPGs) as high-radiation-dose sensors. IEEE Photon. Technol. Letters 24: 742744.

12. Chiavaioli F, Biswas P, Trono C, Bandyopadhyay S, Giannetti A, Tombelli S, Basumallick N, Dasgupta K and Baldini F, 2014. Towards sensitive label-free immunosensing by means of turn-around point long period fiber gratings. Biosensors and Bioelectronics. 60: 305-310.

13. Tripathi S M, Bock W J, Mikulic P, Chinnappan R, Ng A, Tolba M and Zourob M, 2012. Long period grating based biosensor for the detection of Escherichia coli bacteria. Biosensors and Bioelectronics. 35: 308-312. 
14. Fang Y and Ramasamy R P, 2015. Current and prospective methods for plant disease detection. Biosensors. 5: 537-561.

15. Poole N F and Arnaudin M E, 2014. The role of fungicides for effective disease management in cereal crops. Canadian J. Plant Pathol. 36: 1-11.

16. Druzhinina I S, Komoń-Zelazowska M, Kredics L, Hatvani L, Antal Z, Belayneh T and Kubicek C P, 2008. Alternative reproductive strategies of Hypocrea orientalis and genetically close but clonal Trichoderma Longibrachiatum, both capable of causing invasive mycoses of humans. Microbiology. 154: 3447-3459.

17. Miller J D, Rand T G and Jarvis B B, 2003. Stachybotrys chartarum: cause of human disease or media darling? Medical Mycology. 41: 271-291.

18. Hatvani L, Antal Z, Manczinger L, Szekeres A, Druzhinina I S, Kubicek C P, Nagy A, Nagy E, Vágvölgyi C and Kredics L, 2007. Green mold diseases of Agaricus and Pleurotus spp. are caused by related but phylogenetically different Trichoderma species. Phytopathology. 97: 532-537.

19. Schuster A and Schmoll M, 2010. Biology and biotechnology of Trichoderma. Appl. Microbiology and Diotechnology. 87: 787-799.

20. Prakash O, Dixit S K and Bhatnagar R, 2002. On the role of the coherence width and its evolution in a short-pulse fundamental beam in second harmonic generation from beta-barium borate. IEEE J. Quant. Electron. 38: 603-613.

Gambhir M., Gupta S., John P., Mahakud R., Kumar J. and Prakash O. 2017. Detection of fungi using a long-period fibre grating. Ukr.J.Phys.Opt. 18: 77 - 82.

Анотація. Вперше продемонстровано можливість застосування довгоперіодичних волоконних дифракційних траток, записаних за допомогою лазера на парах міді, для виявлення грибів у рослинах. ЦІ довгоперіодичні гратки використано для ідентифікачії видів грибів Trichoderma. Значимість наших об'єктів полягає в тому, щзо иі біоагенти захищають коріння рослин від патогенних мікроорганізмів, які можуть викликати серйозні грибкові захворювання, щзо призводять до значних втрат врожайності $i$, крім того, изі об'єкти можуть мати летальний вплив на людину. Такі види Trichoderma як T. Harzianuт, T. Viride i T. Longibacterium виявляють характерні піки загасання відповідно на резонансних довжинах хвиль 1524, 1520 i 1522 нм. Відповідні провали в оптичному пропусканні зменшуються від 63,75 дБ для води до 54,85, 57,34 i 59,76 дБ для водних розчинів T. Harzianum, T. Viride i T. Longibacterium, відповідно. 